\title{
PEMODELAN DAN ANALISIS PERUBAHAN GARIS PANTAI DI KABUPATEN SITUBONDO, JAWA TIMUR
}

\author{
M. Arif Zainul Fuad ${ }^{a *}$, Annisa Kusuma Fajaria ${ }^{\text {, Nurin Hidayatiab }}$ \\ aProgram Studi Ilmu Kelautan, Fakultas Perikanan dan Kelautan, Universitas Brawijaya \\ ${ }^{\mathrm{b}}$ Marine Resources Exploration and management Research Group (RG-MEXMA) FPIK- Universitas \\ Brawijaya \\ Jalan. Veteran, Malang, Jawa Timur \\ *Koresponden penulis: fuad_maz@ub.ac.id
}

\begin{abstract}
Abstrak
Pesisir Kabupaten Situbondo yang terletak di pantai utara Jawa diduga cenderung mengalami akresi. Akan tetapi terdapat beberapa daerah di Situbondo yang rawan abrasi, seperti daerah Banyuglugur dan Besuki. Kecamatan Banyuglugur, Besuki, Mlandingan, dan Suboh merupakan daerah pesisir yang padat pemukiman dan rawan terhadap perubahan. Oleh sebab itu dilakukan prediksi perubahan garis pantai menggunakan one-line model agar dapat meminimalisir dampak yang akan terjadi. Data utama untuk memodelkan prediksi garis pantai adalah koordinat garis pantai, kemiringan pantai, dan gelombang. Dilakukan perhitungan transpor sedimen menggunakan rumus CERC untuk mengetahui erosi maupun akresi. Kemudian didapat perubahan garis pantai berdasarkan waktu yang ditentukan. Berdasarkan hasil prediksi menggunakan one-line model, terdapat daerah di pesisir bagian barat Kabupaten Situbondo yang diprediksi mengalami erosi dan akresi. Erosi terjadi di lokasi Pantai Tampora, pemukiman Banyuglugur, tambak Kecamatan Suboh, dan tanah kosong di TPI Mlandingan. Akresi akan dominan terjadi di lokasi mangrove Kecamatan Banyuglugur, muara Sungai Lobawang, muara Sungai Deluang, Pantai Dubibir, mangrove Kecamatan Suboh, dan muara Sungai Gardu Rusak. Pada lokasi yang mengalami garis pantai mundur, pola transpor sedimennya termasuk dalam kategori erosion. Sedangkan area yang mengalami garis pantai maju memiliki pola transpor yang termasuk dalam kategori transport as bed load. Secara kseluruhan, area penelitian mengalami akresi dengan laju akresi sebesar 0,217 m/tahun.
\end{abstract}

Kata kunci: Garis pantai, one-line model, Situbondo

\begin{abstract}
Shoreline in Coastal of Situbondo, that located in north Java coastal, is suspected to be accretion. However, there are several areas in Situbondo that suscetible to abrasion, such as Banyuglugur and Besuki. Coastal area of Banyuglugur, Besuki, Mlandingan, and Suboh are highly populated and suscetible of shoreline change. Therefore, research about prediction of shoreline changes using a one-line model is needed to minimize the impact that will occur. The main data of this research are shoreline coordinates, beach slope, and waves data. For the sediment transport was calculated with CERC formula to determine erosion and accretion. Then the shoreline changes are obtained based on the specified time. Prediction results show that the shoreline in this area will change beacuse of erosion and accretion for several years later. Erosion will occur in Tampora Beach, Banyuglugur settlement, shrimp ponds of Suboh area, and unused land in Mlandingan fish market. Accretion will occur in Banyuglugur mangrove area, Lobawang River estuary, Deluang River estuary, Dubibir Beach, Suboh mangrove area, and Gardu Rusak River estuary. At area that predicted has backward shoreline, pattern of sediment transport is erosion. Area that predicted has developed shoreline; the category of transport sediment is transport as bed load. Overall, the shoreline in study area will change with accretion rate $0,217 \mathrm{~m} /$ year
\end{abstract}

Keywords: Shoreline, one line model, Situbondo

\section{LATAR BELAKANG}

Garis pantai merupakan garis semu yang digunakan sebagai pembatas antara daratan dan lautan. Garis pantai sangat dinamis dan sering terjadi perubahan. Perubahan garis pantai yang terjadi antara daerah satu dengan lainnya memiliki karakteristik yang berbeda 
tergantung jenis sedimen, faktor hidrooseanografi, dan kegiatan antropogenik yang dapat mengganggu kestabilan pantai.

Situbondo memiliki garis pantai sepanjang $131,575 \mathrm{~km}$ dan sebagian masyarakat Situbondo bermukim di daerah pesisir [1]. Kabupaten Situbondo termasuk daerah pantai utara yang diduga cenderung mengalami pertambahan sedimen atau akresi sehingga terbentuk lahan baru yang dapat mengakibatkan perselisihan. Akan tetapi terdapat beberapa daerah di Situbondo yang rawan abrasi, seperti daerah Banyuglugur dan Besuki [2]. Pesisir Kecamatan Banyuglugur, Besuki, Suboh, dan Mlandingan merupakan wilayah yang padat pemukiman. Adanya alih fungsi lahan di daerah tersebut dapat mengurangi luasan wilayah pesisir dan mengakibatkan ketidakstabilan garis pantai.

Terdapat beberapa pendekatan untuk mengetahui perubahan garis pantai di suatu daerah, seperti pendekatan sedimen, penginderaan jauh, dan numerik. Metode oneline model dipilih karena dapat memodelkan sesuai tahun yang diinginkan, diketahui besar angkutan sedimen, dan kompatibel di berbagai komputer. Besaran angkutan sedimen pada one-line model dihitung menggunakan rumus Coastal Engineering Research Center
(CERC). CERC merupakan rumus yang diturunkan untuk pantai dengan substrat berpasir (Arafat dan Hidayat, 2011), sehingga rumus ini dapat diterapkan di daerah penelitian dengan sedimen berpasir.

Tujuan utama dilakukannya penelitian ini adalah memprediksikan perubahan garis pantai menggunakan one-line model untuk 5 hingga 25 tahun kemudian serta mengetahui pola transpor sedimen yang terjadi di pesisir bagian barat Kabupaten Situbondo.

\section{METODE PENELITIAN}

Penelitian ini dilakukan di sepanjang pesisir bagian barat Kabupaten Situbondo, Jawa Timur dengan panjang garis pantai 20 kilometer yang mencakup Kecamatan Banyugluglur, Besuki, Suboh, dan Mlandingan yang dibagi menjadi 15 lokasi bagian sesuai dengan profil pantai (Gambar 1). Penelitian dilakanakan mulai bulan Februari hingga Maret 2020. Pengambilan data lapang duilakukan pada tanggal 18 - 23 Februari 2020 di pesisir bagian barat Kabupaten Situbondo. Pengolahan untuk analisis sampel sedimen dilakukan pada bulan Maret 2020 di Laboratorium Tanah dan Air Tanah, Fakultas Teknik, Universitas Brawijaya.

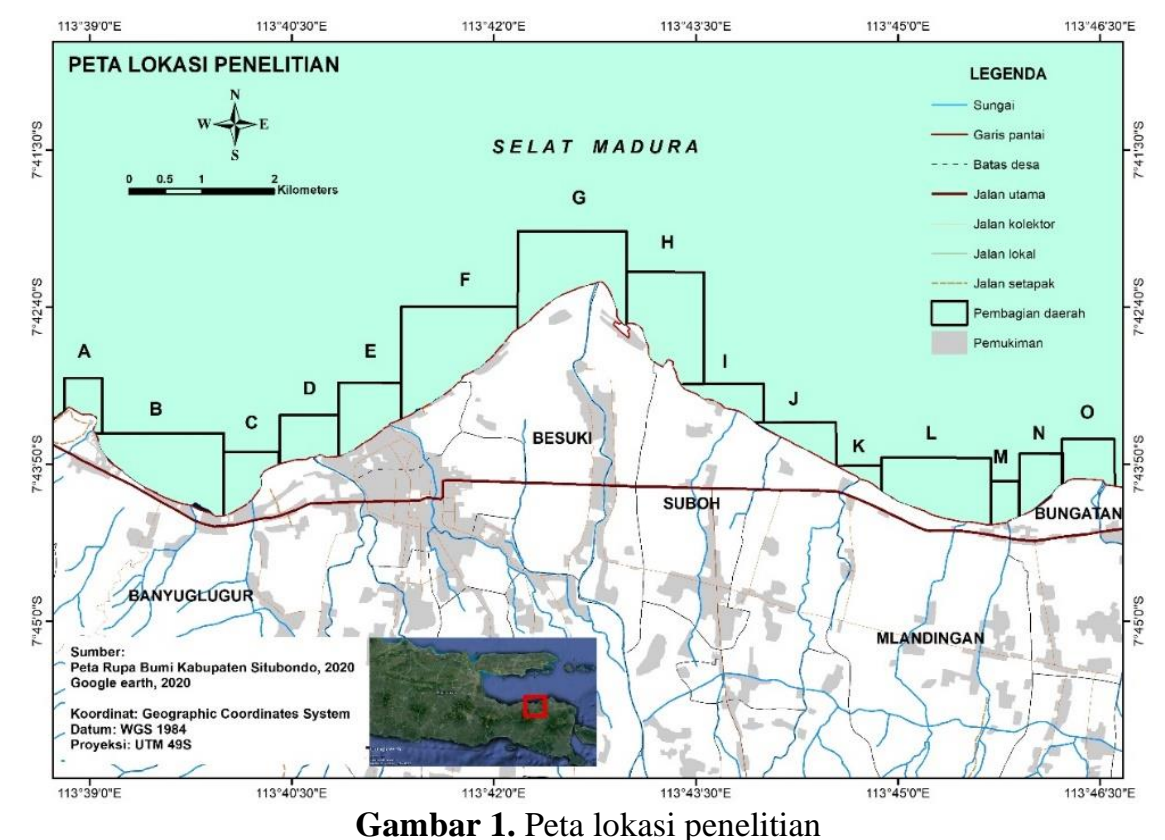

Pengumpulan data

Data yang dibutuhkan dan diukur secara langsung adalah koordinat garis pantai, 
kemiringan pantai, tinggi dan periode gelombang, pasang surut, arus, dan sedimen. Pengukuran kemiringan pantai, tinggi, periode, dan arah gelombang dilakukan di 15 stasiun yang mewakili masing-masing lokasi bagian (Gambar 2). Pengukuran arus dan sedimen dilakukan di 25 stasiun berdasarkan lokasi yang berpotensi sebagai sumber transpor sedimen dan mewakili masing-masing lokasi bagian (Gambar 3). Selain itu digunakan juga data pasang surut dari Badan Informasi Geospasial (BIG), data arus dari The Physical Oceanography Distributed Active Archive Center (PODAAC), dan citra Google Earth tahun 2009, 2013, 2016, dan 2019 sebagai data pendukung.

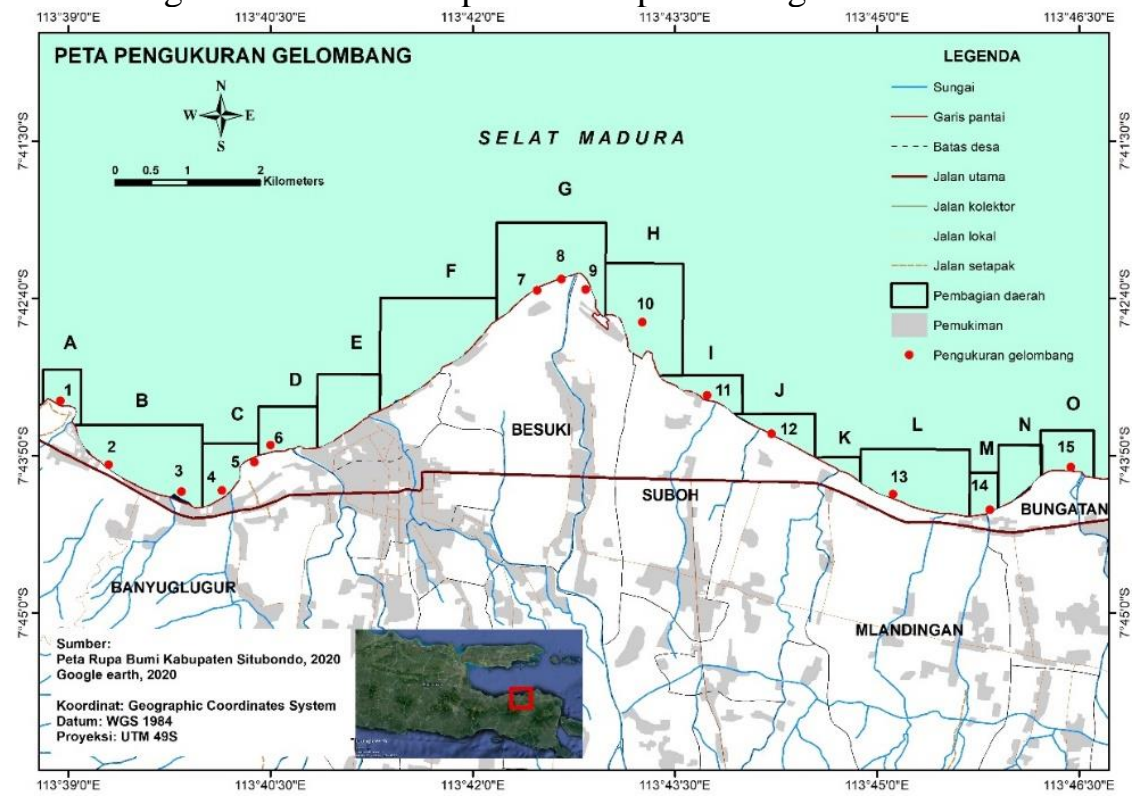

Gambar 2. Peta lokasi pengukuran gelombang dan kemiringan

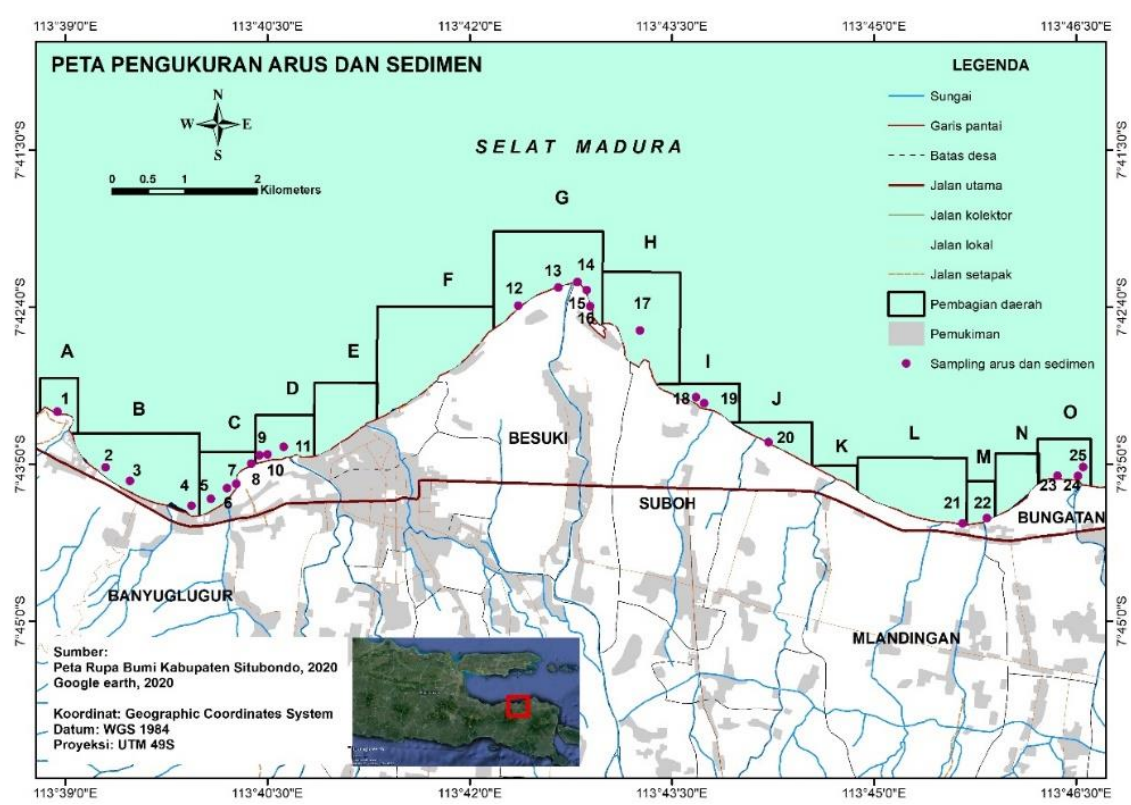

Gambar 3. Peta lokasi pengukuran data arus

\section{Pengolahan data}

Data gelombang dan kemirinagn pantai digunakan untuk menentukan tinggi gelombang pecah dan kedalaman gelombang pecah. Tinggi gelombang pecah (hb) dihitung menggunakan rumus:

$$
\frac{h_{0}}{\mathrm{gT}^{2}}
$$


Dimana $h_{0}$ adalah tinggi gelombang hasil pengukuran lapang, $\mathrm{g}$ adalah gravitasi bumi $\left(9.81 \mathrm{~m} / \mathrm{s}^{2}\right)$, dan $\mathrm{T}$ adalah periode gelombang hasil pengukuran di lapang. Kemudian diplotkan ke grafik tinggi gelombang pecah untuk diketahui nilai hb. Nilai kedalaman gelombang pecah $(\mathrm{db})$ dihitung dengan rumus:

$$
\frac{\mathrm{h}_{\mathrm{b}}}{\mathrm{gT}^{2}}
$$

Setelah itu diplotkan ke grafik kedalaman gelombang pecah untuk diketahui nilai $\mathrm{db}$.

Data pasang surut hasil pengukuran di lapang dan BIG dihitung menggunakan admiralty untuk didapatkan bilangan formzahl dan diketahui tipe pasang surutnya. Data arus dibuat kontur berdasarkan kecepatan dan arah arus.

Sampel sedimen yang telah dikeringkan, ditimbang, dan diayak menggunakan shieve shaker dipisahkan berdasarkan ukuran butir sedimen untuk diketahui ukuran dan jenis sedimen. Setelah itu dilakukan analisis granulometri yang meliputi mean (rata-rata ukuran sedimen), sorting (tingkat keseragaman), skewness, dan kurtosis. Selanjutnya data ukuran butir sedimen dan arus dapat digunakan untuk penentuan transpor sedimen yang diplotkan menngunakan kurva Hjulstrom.

Pengolahan data garis pantai meliputi tahap pengolahan data citra dan prediksi perubahan garis pantai. Pengolahan data citra dilakukan dengan ditentukan titik awal hingga titik akhir sebagai koordinat garis pantai sesuai dengan prediksi yang akan dibuat dan overlay untuk mengetahui perubahan garis pantai yang telah terjadi. Besaran akresi dan erosi dihitung menggunakan metode One Line Model yaitu modifikasi single transek (Gambar 4). Single transek dihitung dengan menentukan baseline dan transek. Baseline ditentukan dari garis pantai awal, sedangkan transek merupakan penarikan garis tegak lurus dari baseline ke garis pantai yang lain dengan jarak antar transek $25 \mathrm{~m}$. Setelah tu didapat besaran ekresi dan erosi. Nilai negatif menunjukkan erosi, sedangkan positif menunjukkan akresi.

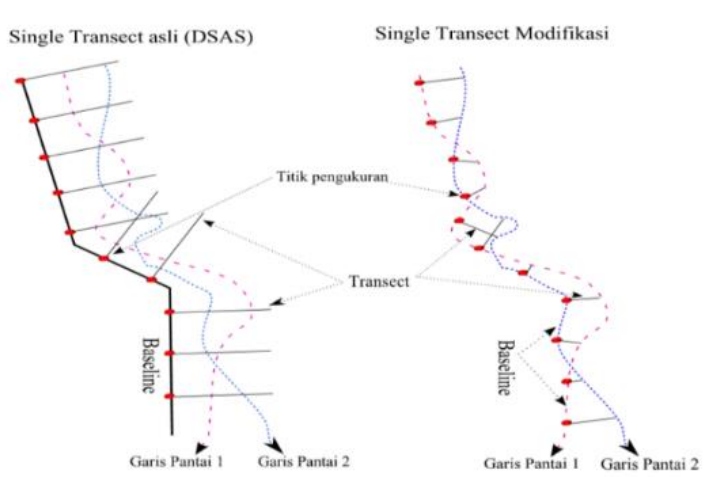

Gambar 4. Modifikasi single transek [4]

Prediksi perubahan garis pantai menggunakan one-line model dilakukan untuk 5 hingga 25 tahun menggunakan rumus CERC (Coastal Engineering Research Center). Rumus CERC cocok digunakan untuk pantai berpasir seragam. Data yang digunakan untuk metode one-line model adalah data koordinat garis pantai, kemiringan pantai, $\mathrm{h}_{\mathrm{b}}, \mathrm{d}_{\mathrm{b}}$, dan arah gelombang. Arah gelombang dibuthkan sebab dapat mempengaruhi transpor sedimen. Sudut datang akan berbeda antar sel akibat profil pantai (Gambar 5).

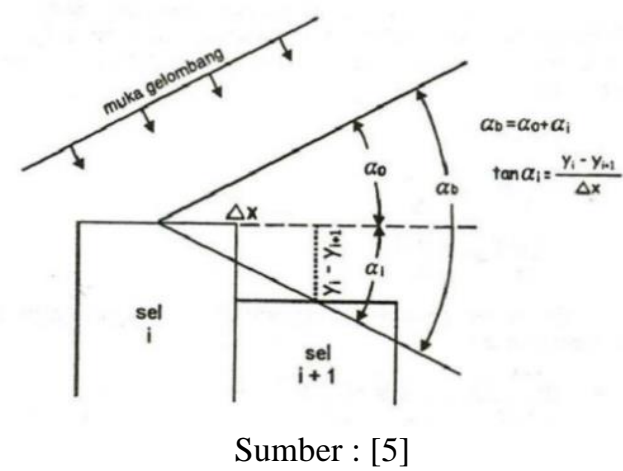

Gambar 5. Hubungan $\alpha_{0}, \alpha_{\mathrm{i}}$, dan $\alpha_{\mathrm{b}}$

Langkah pertama dilakukan pembagian lokasi berdasarkan profil pantai. Kemudian dihitung komponen fluks energi gelombang berdasarkan tinggi, periode, dan arah gelombang dengan rumus berikut:

$$
\mathrm{P}_{\mathrm{i}}=\frac{\rho \mathrm{g}}{8} \mathrm{H}_{\mathrm{b}^{2}} \mathrm{C}_{\mathrm{b}} \sin \alpha_{\mathrm{b}} \cos \alpha_{\mathrm{b}} \text { (3) }
$$

$\mathrm{P}_{1} \quad$ : Komponen fluks energi gelombang sepanjang pantai pada saat pecah (ton $\mathrm{m} / \mathrm{hari} / \mathrm{m}$ )

$\rho \quad:$ Rapat masa air laut (ton $\left./ \mathrm{m}^{3}\right)$

$\alpha_{0} \quad$ : Sudut gelombang datang

$\mathrm{H}_{\mathrm{b}} \quad$ : Tinggi gelombang pecah (m)

$\mathrm{C}_{\mathrm{b}} \quad$ : Cepat rambat gelombang pecah

g : Gravitasi bumi $\left(\mathrm{m} / \mathrm{s}^{2}\right)$ 
$\alpha_{\mathrm{b}} \quad$ : Sudut datang gelombang pecah

$\mathrm{d}_{\mathrm{b}} \quad$ : Kedalaman gelombang pecah

$\alpha_{\mathrm{i}} \quad$ : Sudut yang dibentuk oleh garis pantai dengan garis sejajar sumbu $\mathrm{x}$

$\mathrm{y}_{\mathrm{i}} \quad$ : Garis yang dibentuk sejajar sumbu y

\section{HASIL DAN PEMBAHASAN}

\section{Kondisi hidrooseanografi}

Tinggi gelombang yang terjadi di perairan pesisir bagian barat Kabupaten Situbondo sebesar 0,15-0,38 $\mathrm{m}$ dengan periode 1,9-3,61 s dan arah gelombang dari timur hingga tenggara. Tinggi gelombang yang tertinggi terjadi di daerah wisata Pantai Tampora, sedangkan tinggi gelombang terendah terjadi di daerah muara Sungai Lobawang dan daerah mangrove di Kecamatan Suboh. Daerah penelitian memiliki kemiringan yang cukup landai sehingga tipe gelombang pecah berupa spilling. Pada wilayah pantai Tampora memiliki tipe gelombang pecah berupa plunging. Spilling breaker memiliki sifat membangun pantai, sedangkan plunging breaker dapat menyebabkan erosi [6]. Oleh sebab itu, sebagian besar wilayah penelitian terjadi akresi.

Tipe pasang surut di area penelitian adalah campuran condong ganda (Gambar 6). Hal tersebut diketahui dari bilangan formzahl yang didapat sebesar 0,99 . Data pasang surut dari BIG juga menunjukkan bahwa tipe pasang surut campuran condong ganda. Nilai dari bilangan formzahl pasang surut dari data BIG sebesar 0,74. Tipe pasang surut campuran condong ganda ditunjukkan dengan nilai formzahl $0,25<\mathrm{F}<1,5$.

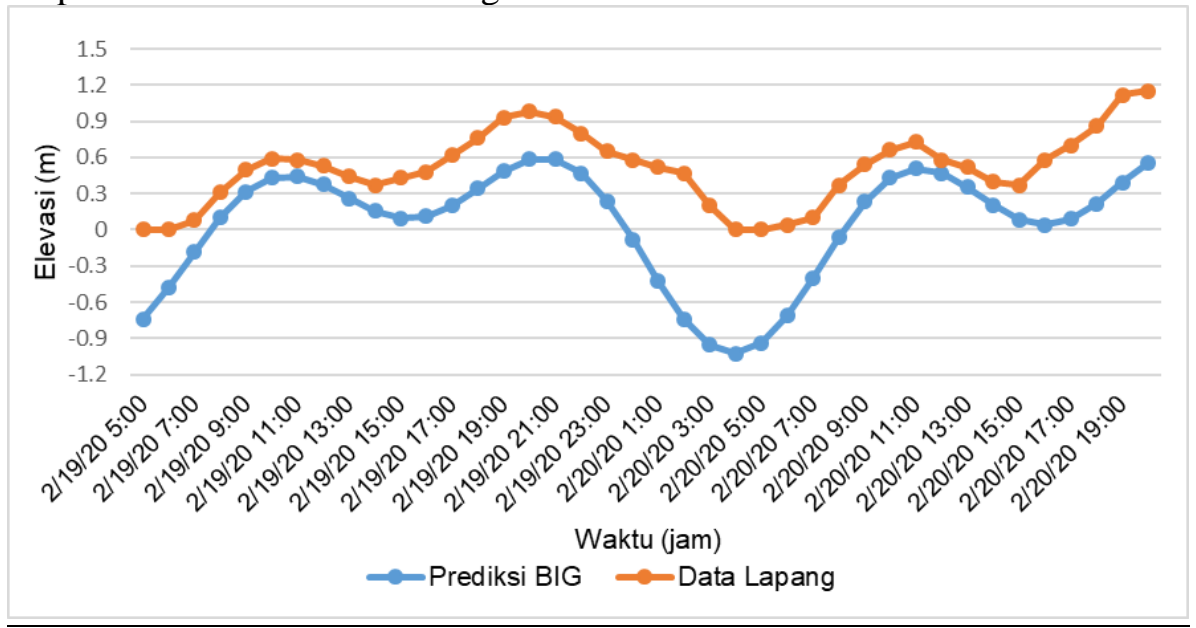

Gambar 6. Grafik pasang surut pesisir barat Kabupaten Situbondo

Perairan utara Jawa Timur memiliki 2 tipe pasang surut, yaitu pasang surut harian tunggal dan campuran cenderung harian ganda. Daerah Tuban, Lamongan, dan perairan utara gresik memiliki tipe pasang surut harian tunggal, sedangkan perairan Pasuruan, Probolinggo, dan Situbondo memiliki tipe pasang surut campuran codong harian ganda [7].

Kecepatan arus di lokasi penelitian menggunakan data PODAAC sebesar 0,1-0,05 $\mathrm{m} / \mathrm{s}$ dengan arah dari barat daya menuju timur laut (Gambar 7). Hasil pengkuran arus yang diambil langsung tanggal 19-22 Februari 2020 (Gambar 8) menunjukkan kecepatan terendah terjadi di daerah muara Sungai Gardu Rusak sebesar $0,1335 \mathrm{~m} / \mathrm{s}$. Kecepatan arus tertinggi ada di daerah muara Sungai Deluang sebesar $0,5657 \mathrm{~m} /$ detik. Kecepatan arus di sebelah barat rata-rata lebih kencang daripada arus yang ada di sebelah timur. Hal ini disebabkan pada saat pengukuran arus di bagian barat area penelitian dilakukan pada saat pasang menuju surut, sehingga kecepatan arus yang terjadi cenderung lebih kencang daripada area timur penelitian. Kecepatan arus cukup tinggi terjadi saat menjelang surut dan kecepatan arus terendah terjadi pada saat menuju pasang [8] Arah arus di sisi barat lokasi penelitian dominan dari selatan hingga barat daya menuju ke Selat Madura. Pada sisi timur daerah 
penelitian arah arus yang dominan dari barat

laut menuju ke daratan.

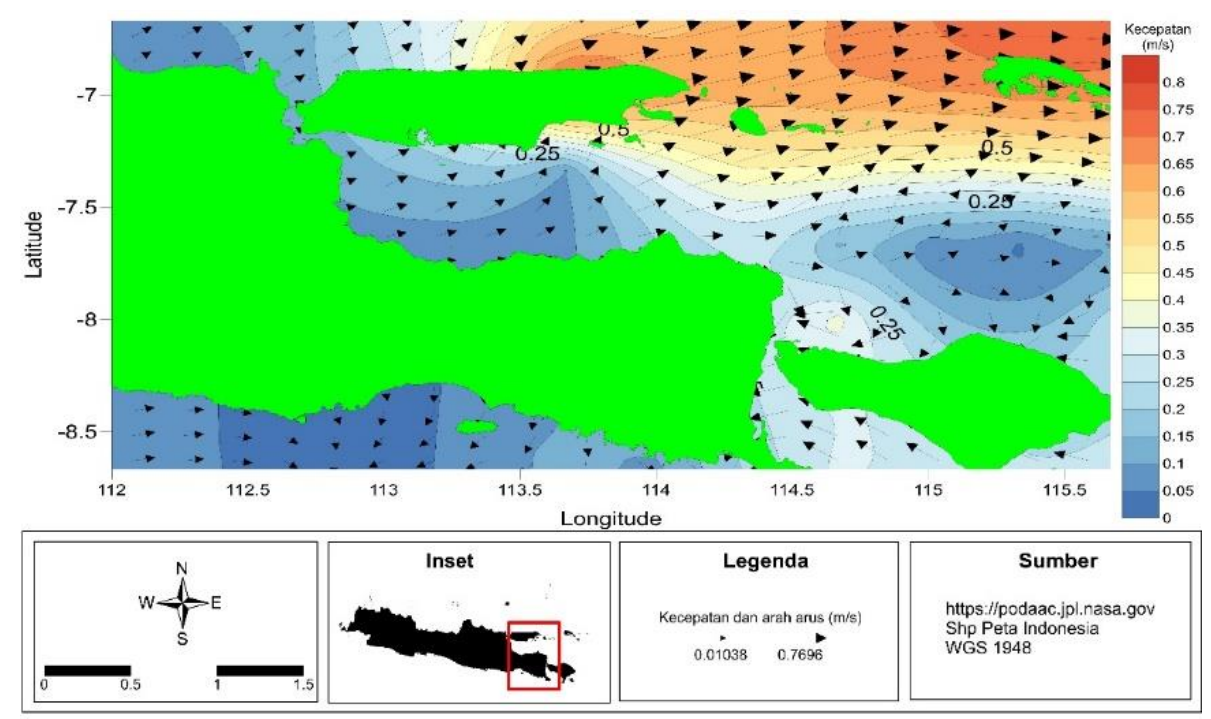

Gambar 7. Peta pola sebaran arus Jawa Timur tahun 2019

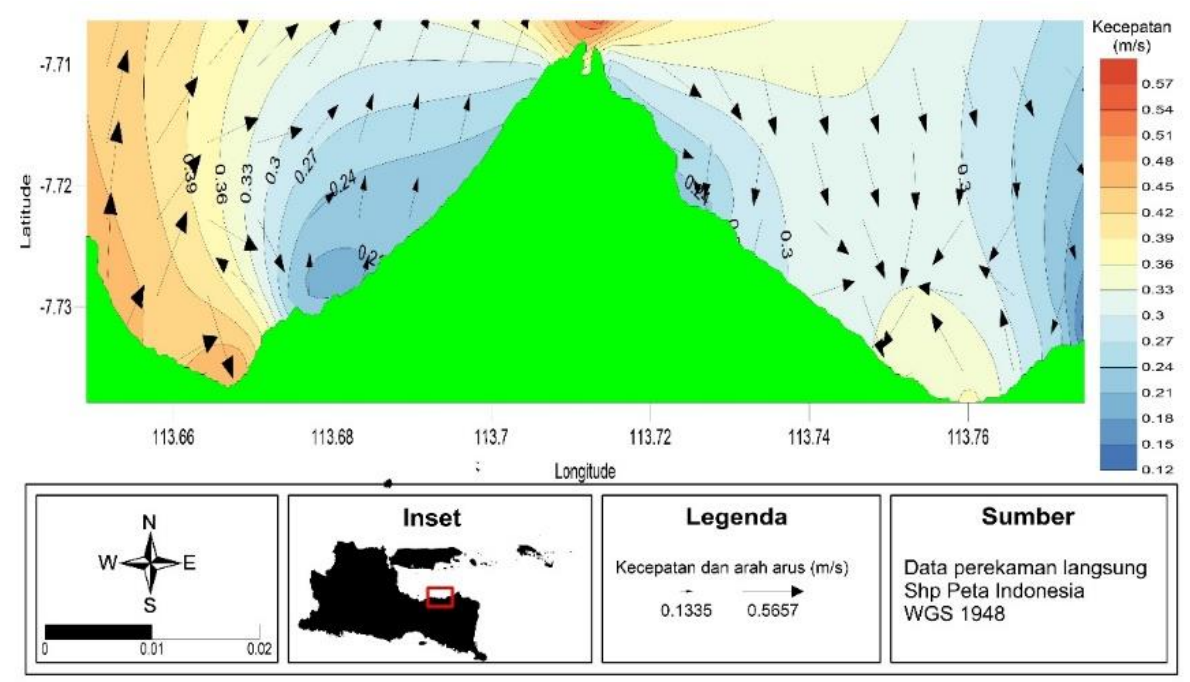

Gambar 8. Peta pola sebaran arus data lapang tahun 2020

\section{Ukuran dan jenis sedimen}

Sedimen pada stasiun 1 merupakan pasir putih yang bercampur dengan rubble atau patahan karang dan cangkang kerang mati. Pada stasiun 2-4 berupa pasir hitam dengan campuran foraminifera dan sedikit cangkang kerang. Stasiun 5-25 memiliki sedimen berupa pasir hitam. Berdasarkan persentase fraksi sedimen dengan skala Wentworth, ukuran sedimen dominan antara 0,6 - 0,15 mm dengan fraksi pasir sedang hingga halus (Gambar 9). Secara keseluruhan jenis sedimen yang diplotkan ke dalam segitiga Shepard adalah pasir (Gambar 10). 


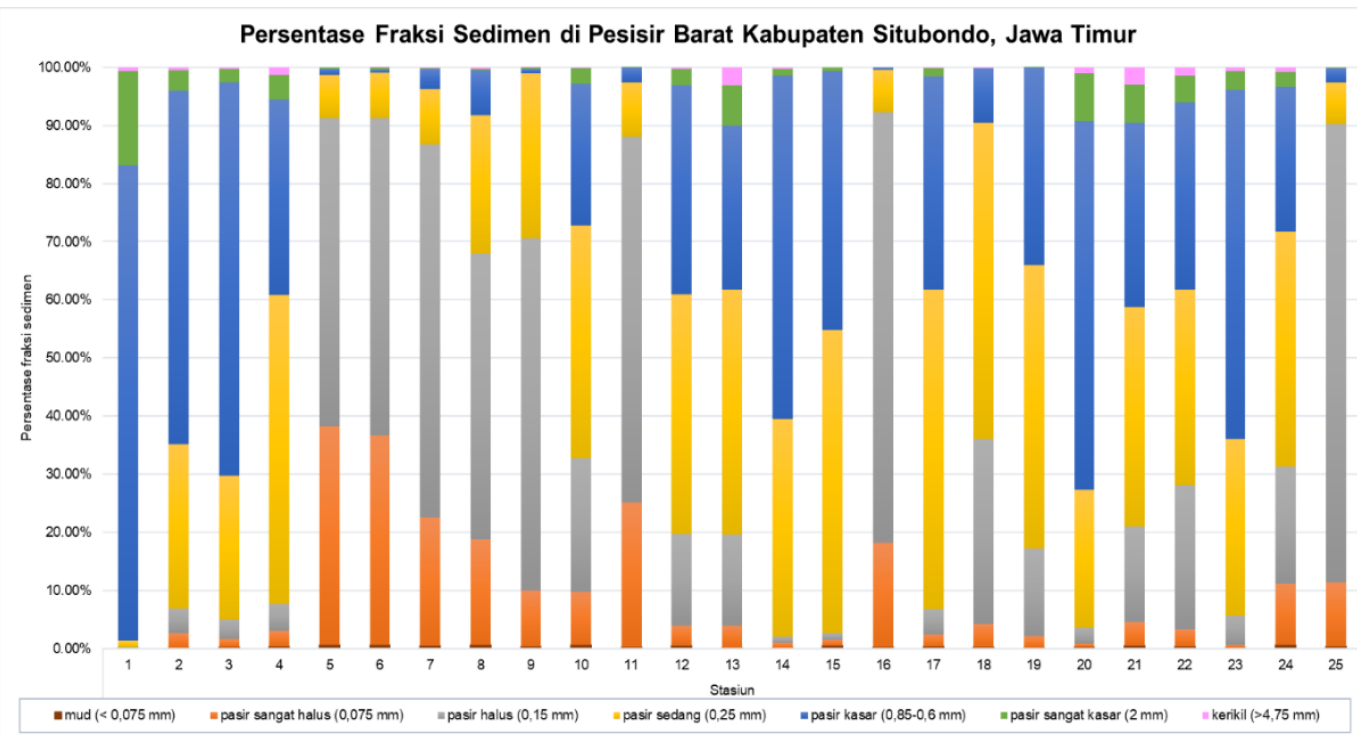

Gambar 9. Persentase fraksi sedimen

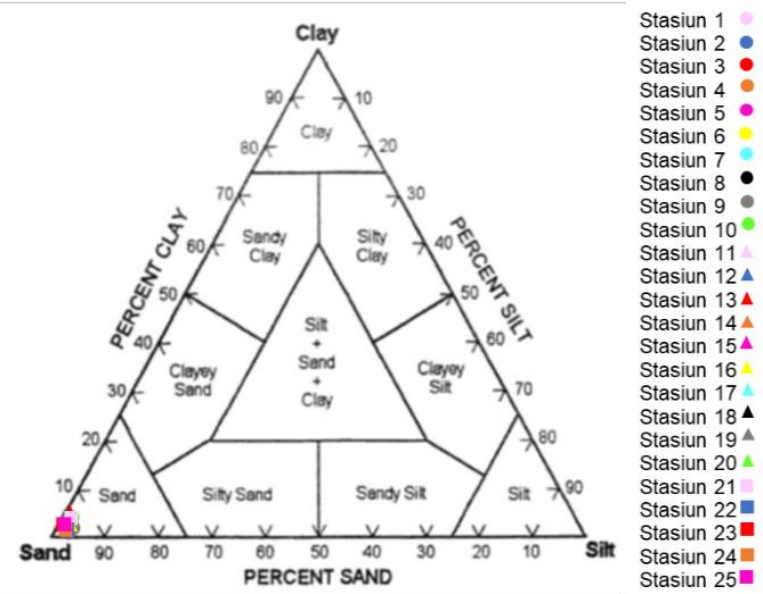

Gambar 10. Jenis sedimen berdasarkan segitiga Shepard

Setelah mengetahui ukuran dan jenis sedimen, selanjutnya dilakukan pengolahan analisis granulometri meliputi mean, sorting, skewness, dan kurtosis. Wilayah muara sungai dan daerah terbuka seperti Pantai Tampora, pemukiman, dan tanah kosong memiliki ukuran sedimen yang relatif lebih besar. Daerah mangrove dan setelah muara sungai memiliki sedimen yang relatif lebih halus. Daerah mangrove memiliki ukuran sedimen lebih halus yang disebabkan oleh adanya akar mangrove dapat mereduksi arus yang datang. Arus yang datang tersebut akan menjadi lemah dan memberi kesempatan butiran halus untuk lebih banyak terdeposisi di daerah mangrove

Tabel 1. Ukuran butir sedimen dan kecepatan arus
[9]. Daerah setelah muara juga memiliki ukuran butiran yang lebih kecil sebab fraksi yang halus dari muara sungai mudah terbawa dan mengendap di lokasi setelah muara sungai. Menurut Nugroho dan Basit (2014), ketika adanya arus yang kuat sedimen yang memiliki fraksi yang kasar tidak mudah terbawa arus, namun sedimen yang halus terbawa dan mengendap di daerah yang lebih tenang. Kondisi arus di lokasi setelah muara sungai Lobawang, Kecamatan Besuki, dan Gardu Rusak lebih tenang daripada lokasi tepat di muara sungai (Tabel 1) sehingga fraksi yang halus terbawa di sisi setelah muara sungai 


\begin{tabular}{|c|c|c|c|c|}
\hline Lokasi & Stasiun & $\begin{array}{l}\text { Mean } \\
(\mathrm{mm})\end{array}$ & $\begin{array}{c}\text { Fraksi } \\
\text { Sedimen }\end{array}$ & $\begin{array}{l}\text { Kecepatan Arus } \\
(\mathbf{m} / \mathbf{s})\end{array}$ \\
\hline A (Pantai Dubibir) & 1 & 1,26 & Pasir kasar & 0,47 \\
\hline B (tanah kosong) & 2 & 0,68 & Pasir kasar & 0,47 \\
\hline B (pemukiman) & 3 & 0,70 & Pasir kasar & 0,43 \\
\hline B (pemukiman dekat mangrove) & 4 & 0,49 & Pasir sedang & 0,47 \\
\hline $\mathrm{C}$ (mangrove dekat pemukiman) & 5 & 0,16 & Pasir halus & 0,47 \\
\hline $\mathrm{C}$ (mangrove barat) & 6 & 0,16 & Pasir halus & 0,43 \\
\hline $\mathrm{C}$ (mangrove tengah) & 7 & 0,18 & Pasir halus & 0,40 \\
\hline $\mathrm{C}$ (mangrove timur) & 8 & 0,23 & Pasir halus & 0,33 \\
\hline D (sebelum muara Sungai Lobawang) & 9 & 0,23 & Pasir halus & 0,23 \\
\hline D (muara Sungai Lobawang) & 10 & 0,37 & Pasir sedang & 0,23 \\
\hline D (setelah muara Sungai Lobawang) & 11 & 0,18 & Pasir halus & 0,20 \\
\hline G (tanah kosong) & 12 & 0,48 & Pasir sedang & 0,27 \\
\hline G (sebelum muara Sungai Deluang) & 13 & 0,51 & Pasir kasar & 0,47 \\
\hline G (muara Sungai Deluang) & 14 & 0,63 & Pasir kasar & 0,57 \\
\hline G (setelah muara sungai Deluang) & 15 & 0,50 & Pasir sedang & 0,30 \\
\hline $\begin{array}{l}\mathrm{G} \text { (tanah kosong setelah muara Sungai } \\
\text { Deluang) }\end{array}$ & 16 & 0,18 & Pasir halus & 0,27 \\
\hline H (Pantai Dubibir) & 17 & 0,41 & Pasir sedang & 0,27 \\
\hline I (mangrove barat) & 18 & 0,32 & Pasir sedang & 0,23 \\
\hline I (mangrove timur) & 19 & 0,43 & Pasir sedang & 0,27 \\
\hline $\mathrm{J}$ (tanah kosong) & 20 & 0,80 & Pasir kasar & 0,30 \\
\hline L (tanah kosong) & 21 & 0,51 & Pasir kasar & 0,37 \\
\hline M (tanah kosong setelah jetty) & 22 & 0,47 & Pasir sedang & 0,33 \\
\hline O (sebelum muara Sungai Gardu Rusak) & 23 & 0,71 & Pasir kasar & 0,23 \\
\hline O (muara Sungai Gardu Rusak) & 24 & 0,37 & Pasir sedang & 0,17 \\
\hline O (setelah muara Sungai Gardu Rusak) & 25 & 0,19 & Pasir halus & 0,13 \\
\hline
\end{tabular}

Keseluruhan area penelitian memiliki nilai sorting yang negatif dan diklasifikasikan ke dalam very sell sorted, sehingga sedimen yang ada wilayah tersebut cenderung seragam. Kondisi ukuran sedimen yang relatif seragam menunjukkan bahwa arus di perairan tersebut ralatif stabil dari waktu ke waktu (Ramli et al., 2017).

Nilai skewness daerah penelitian beragam secara umum condong ke arah halus. Hal tersebut menunjukkan apabila butiran sedimen cenderung halus menunjukkan arus yang cenderung lemah [11]. Intensitas

\section{Analisis transpor sedimen}

Kecepatan arus yang cenderung kencang dengan ukuran butir sedimen kecil dapat menyebabkan sedimen terbawa oleh arus, sehingga pola transpor sedimen yang terjadi pergerakan arus dengan energi yang relatif kencang menyebabkan sedimen yang lebih halus terbawa ke arah laut dan sedimen yang kasar yang dapat diendapkan.

Kurtosis pada daerah penelitian dominan leptokurtic. Hasil ini menunjukkan bahwa terdapat sedimen ukuran tertentu yang mendominasi [11]. Berdasarkan Gambar 9 mengenai diagram dimeter ukuran butir sedimen, dapat diketahui bahwa terdapat ukuran sedimen yang mendominasi pada masing-masing stasiun.

berupa erosion (Gambar 11). Pada pantai berpasir pola transpor sedimen akan lebih banyak sebagai bed load (Hatati et al., 2016). Adapun lokasi yang mengalami erosion adalah 
Pantai Tampora, pemukiman hingga mangrove Kecamatan Besuki, muara Sungai Deluang, tambak Kecamatan Suboh hingga Mlandingan, dan TPI Pesisir Mlandingan. Sedangkan lokasi yang pola transpor sedimennya berupa transport as bed load, terdapat di muara Sungai Lobawang, Pantai Dubibir, mangrove Kecamatan Suboh, dan muara Sungai Gardu Rusak.

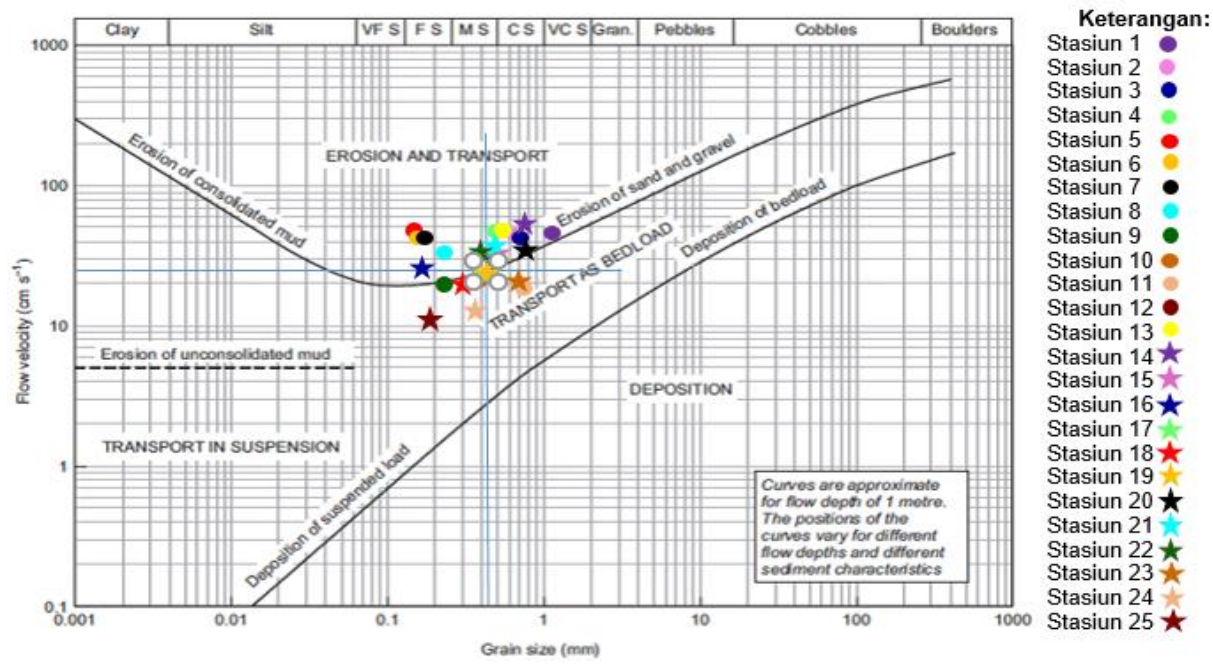

Gambar 11. Kurva Hjulstrom lokasi penelitian

\section{Analisis Perubahan Garis Pantai}

Berdasarkan hasil citra Google Earth (GE) tahun 2009-2019 terdapat beberapa lokasi yang mengalami erosi maupun akresi (Gambar 12). Lokasi bagian A (pantai wisata Tampora) merupakan lokasi yang mengalami erosi signifikan tahun 2009-2019 dengan laju $12,90 \mathrm{~m} /$ tahun (Tabel 2). Lokasi yang mengalami akresi signifikan ada di lokasi D (muara Sungai Lobawang) dengan laju 9,18 /tahun. Selain itu terdapat pula lokasi yang mengalami akresi signifikan, yaitu lokasi $\mathrm{H}$
(Pantai Dubibir) dengan laju 4,94 m/tahun. Pada lokasi M (TPI Pesisir Mlandingan) tahun 2009-2016 memiliki garis pantai yang cenderung mundur. Pada tahun 2019 garis pantai yang ada di lokasi tersebut cenderung maju. hal ini disebabkan pada tahun 2018, terdapat pembangunan revetment di lokasi tersebut.Secara keseluruhan daerah penelitian cenderung mengalami akresi dengan laju ratarata sebesar $0,21 \mathrm{~m} /$ tahun.

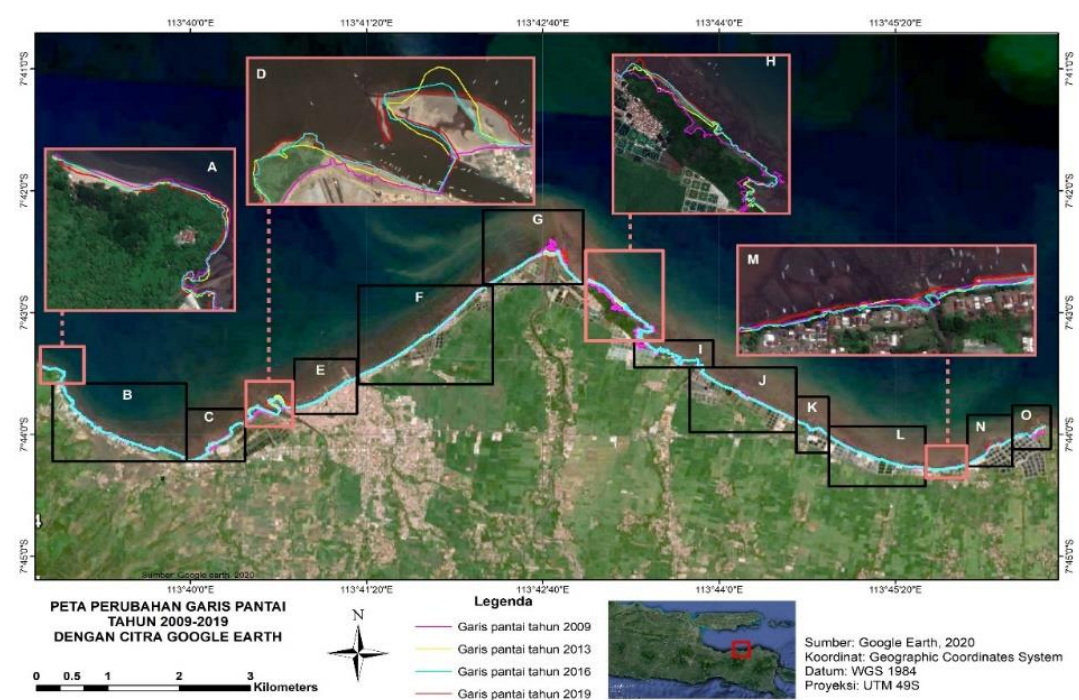

Gambar 12. Perubahan garis pantai pesisir Kabupaten Situbondo 2009-2019 
Tabel 2. Erosi dan akresi berdasarkan hasil citra Google Earth

\begin{tabular}{|c|c|c|c|c|c|c|}
\hline \multirow[b]{2}{*}{ Lokasi bagian } & \multicolumn{4}{|c|}{ Besaran erosi maupun akresi (m) } & \multirow{2}{*}{$\begin{array}{c}\text { Laju per } \\
\text { tahun } \\
(\mathrm{m} / \mathrm{th})\end{array}$} & \multirow[b]{2}{*}{ Keterangan } \\
\hline & $\begin{array}{l}2009- \\
2013\end{array}$ & $\begin{array}{l}\text { 2013- } \\
2016\end{array}$ & $\begin{array}{l}2016- \\
2019\end{array}$ & $\begin{array}{l}2009- \\
2019\end{array}$ & & \\
\hline A (Pantai Tampora) & $-3,00$ & $-2,53$ & $-3,33$ & $-129,02$ & $-12,90$ & Erosi \\
\hline B ( pemukiman) & $-2,89$ & $-3,01$ & $-3,11$ & $-5,81$ & $-0,58$ & Erosi \\
\hline $\begin{array}{l}\mathrm{C} \text { (mangrove dan } \\
\text { pemukiman) }\end{array}$ & 0,06 & 4,63 & 2,13 & 1,64 & 0,16 & Akresi \\
\hline $\begin{array}{l}\text { D (muara Sungai } \\
\text { Lobawang) }\end{array}$ & 85,35 & 17,63 & 10,72 & 91,84 & 9,18 & Akresi \\
\hline E (Pelabuhan Besuki) & 0,00 & 0,00 & 0,00 & 0,00 & 0,00 & Tetap \\
\hline F (Pemukiman) & 0,00 & 0,00 & 0,00 & 0,00 & 0,00 & Tetap \\
\hline G (muara Sungai Deluang) & $-49,02$ & $-11,86$ & 24,63 & 13,72 & 1,37 & Akresi \\
\hline H (Pantai wisata Dubibir) & 28,86 & 26,11 & 6,23 & 49,42 & 4,94 & Akresi \\
\hline I (Area mangrove) & 7,81 & 1,19 & 3,10 & 11,13 & 1,11 & Akresi \\
\hline J (Area tambak udang) & $-8,57$ & $-9,90$ & $-5,13$ & $-21,33$ & $-2,13$ & Erosi \\
\hline K (Area tambak udang) & $-2,17$ & 4,62 & $-0,14$ & 0,87 & 0,09 & Akresi \\
\hline L (Area tambak udang) & $-4,70$ & 3,95 & 3,78 & 1,44 & 0,14 & Akresi \\
\hline M (TPI Pesisir Mlandingan) & $-2,60$ & $-1,70$ & 6,79 & 2,15 & 0,22 & Akresi \\
\hline N (Area tambak udang) & $-7,48$ & $-4,59$ & 3,95 & $-2,45$ & $-0,24$ & Erosi \\
\hline O (muara Sungai Gardu) & 9,12 & 29,48 & $-18,45$ & 18,55 & 1,86 & Akresi \\
\hline
\end{tabular}

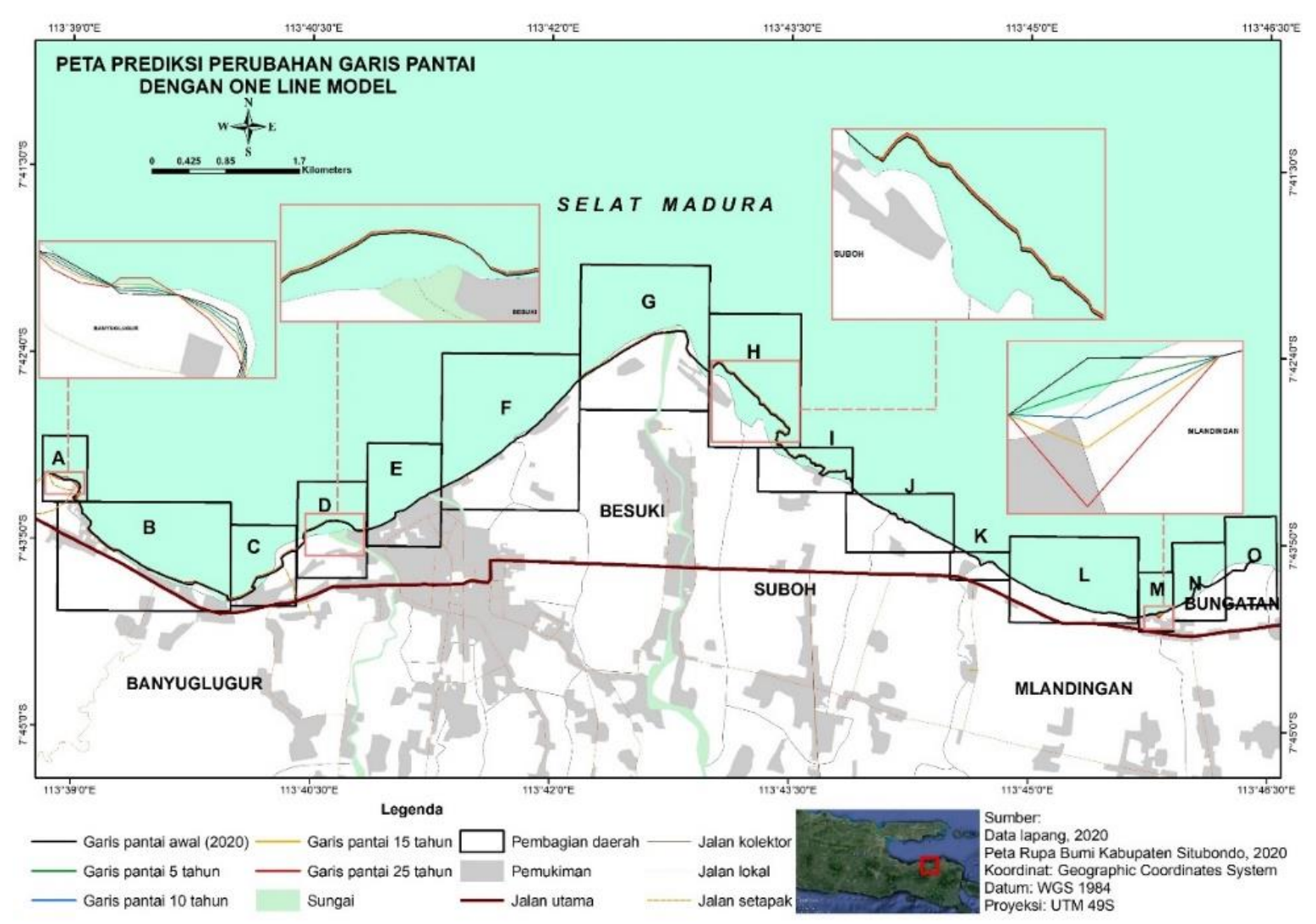

Gambar 13. Prediksi perubahan garis pantai pesisir Kabupaten Situbondo 
Tabel 3. Erosi dan akresi hasil prediksi numerik

\begin{tabular}{|c|c|c|c|c|c|c|}
\hline \multirow[b]{2}{*}{ Lokasi bagian } & \multicolumn{4}{|c|}{ Besaran erosi maupun akresi (m) } & \multirow{2}{*}{$\begin{array}{c}\text { Laju per } \\
\text { tahun } \\
\text { (m/th) }\end{array}$} & \multirow[b]{2}{*}{ Keterangan } \\
\hline & $\begin{array}{c}5 \\
\text { tahun }\end{array}$ & $\begin{array}{c}10 \\
\text { tahun }\end{array}$ & $\begin{array}{c}15 \\
\text { tahun }\end{array}$ & $\begin{array}{c}25 \\
\text { tahun }\end{array}$ & & \\
\hline A (Pantai Tampora) & $-2,811$ & $-5,623$ & $-8,434$ & $-14,057$ & $-0,562$ & Erosi \\
\hline B (daerah pemukiman) & $-0,023$ & $-0,045$ & $-0,068$ & $-0,113$ & $-0,0045$ & Erosi \\
\hline $\begin{array}{l}\mathrm{C} \text { (mangrove } \\
\text { danpemukiman) }\end{array}$ & 2,894 & 5,787 & 8,681 & 14,468 & 0,579 & Akresi \\
\hline D (muara Sungai Lobawang) & 1,556 & 3,113 & 4,669 & 7,782 & 0,311 & Akresi \\
\hline G (muara Sungai Deluang) & 0,993 & 1,986 & 2,979 & 4,965 & 0,199 & Akresi \\
\hline H (Pantai wisata Dubibir) & 3,159 & 6,317 & 9,476 & 15,794 & 0,632 & Akresi \\
\hline I (daerah mangrove) & 1,552 & 3,105 & 4,657 & 7,761 & 0,311 & Akresi \\
\hline J (lokasi tambak udang) & $-0,324$ & $-0,648$ & $-0,972$ & $-1,620$ & $-0,065$ & Erosi \\
\hline L (lokasi tambak udang) & $-0,106$ & $-0,212$ & $-0,318$ & $-0,529$ & $-0,021$ & Erosi \\
\hline M (TPI Pesisir Mlandingan) & $-3,436$ & $-6,873$ & $-10,309$ & $-17,182$ & $-0,687$ & Erosi \\
\hline O (muara Sungai Gardu) & 1,551 & 3,102 & 4,654 & 7,756 & 0,310 & Akresi \\
\hline
\end{tabular}

Prediksi perubahan garis pantai menggunakan one line model untuk 5 hingga 25 tahun ke depan menunjukkan terdapat lokasi yang mengalami akresi maupun erosi (Gambar 13). Berikut merupakan penjelasan mengenai lokasi yang mengalami garis pantai.

\section{a. Prediksi lokasi yang mengalami erosi} signifikan
Daerah A merupakan daerah Pantai Tampora dengan kemiringan paling besar yaitu $0,48 \mathrm{~m}$. Tinggi gelombang yang terjadi juga memiliki nilai paling tinggi daripada lokasi lain yaitu sebesar $0,38 \mathrm{~m}$. Hantaman gelombang yang tinggi menyebabkan penggerusan sehingga mengakibatkan erosi. Di sebelah timur Pantai Tampora terdapat penghalang untuk meredam energi gelombang yang datang (Gambar 14).
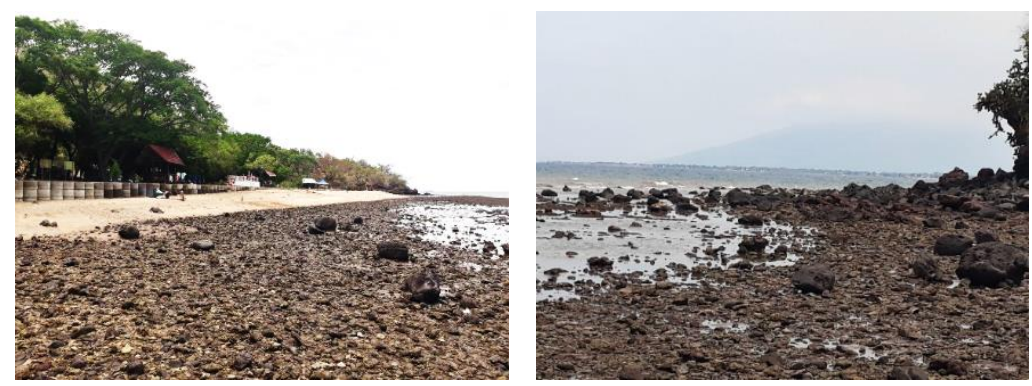

Gambar 14. Lokasi Pantai Tampora

Tanah kosong diantara jetty dan revetment TPI Mlandingan memiliki kemiringan $0,22 \mathrm{~m}$ dan tinggi gelombang sebesar $0,21 \mathrm{~m}$. Arah datang gelombang yang berasal dari timur dapat menggerus sedimen yang ada di lahan kosong dan mengendapkannya di sisi yang dekat dengan jetty (Gambar 15). Sehingga di daerah lahan kosong akan mengalami erosi degan laju sebesar $069 \mathrm{~m} /$ tahun, sedangkan daerah yang di dekat jetty mengalami akresi. Berdasarkan peneltian Fuad et al. (2019), daerah yang dekat dengan jetty di pesisir Tuban mengalami erosi. 

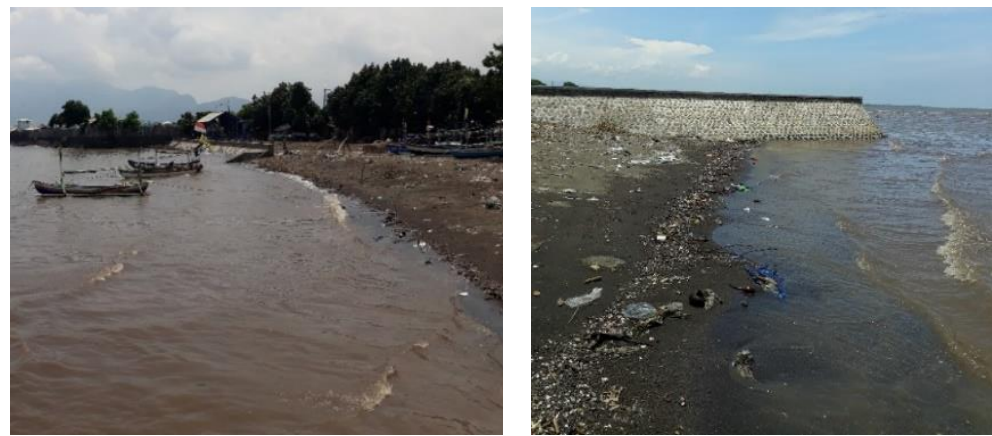

Gambar 15. Lokasi TPI Mlandingan

Daerah yang mengalami erosi merupakan daerah terbuka dan tidak terdapat pelindung pantai seperti daerah Pantai Tampora, pemukiman Kecamatan Banyuglugur, lahan kosong di dekat tambak Kecamatan Suboh, pemukiman dan TPI Mlandingan. Pantai berpasir yang mengalami erosi mendapat energi gelombang tanpa adanya bangunan pelindung pantai Hidayati $e t$ al. (2017). Apabila daerah pemukiman tersebut semakin terkikis akan membahayakan rumah masyarakat pesisir. Menurut Budisusetyo (2009), pada tahun 2007 di Kecamatan Banyuglugur dan Besuki terdapat 133 rumah yang terkena abrasi, dimana 131 rumah berada di Kecamatan Banyuglugur, 2 rumah di Kecamatan Besuki.

\section{b. Prediksi lokasi yang mengalami akresi signifikan}

Pada lokasi bagian $\mathrm{H}$ yang merupakan daerah wisata Pantai Dubibir. Daerah ini memiliki kemiringan yang landai sebesar $0,2 \mathrm{~m}$ dan tinggi gelombang sebesar 0,2 $\mathrm{m}$. Daerah yang memiliki kemiringan pantai yang landai sehingga gelombang yang sampai ke daratan dapat diredam. Menurut Kalay et al. (2018), pesisir pantai yang memiliki tipe kemiringan lereng datar dan landai mempunyai energi gelombang kecil. Energi gelombang yang kecil berpeluang untuk tidak mengikis sedimen yang ada di pantai. Oleh sebab itu diprediksikan untuk beberapa tahun ke depan di daerah ini relatif mengalami garis pantai yang maju.

Hasil prediksi menunjukkan bahwa di lokasi bagian $\mathrm{H}$ dominan terjadi akresi hingga 25 tahun kemudian dengan laju sebesar 0,632 $\mathrm{m} /$ tahun. Sebelumnya garis pantai berada hampir di dekat pemukiman penduduk (Gambar 16a), kemudian terjadi akesi hingga garis pantai maju setelah area mangrove (Gambar 16b).

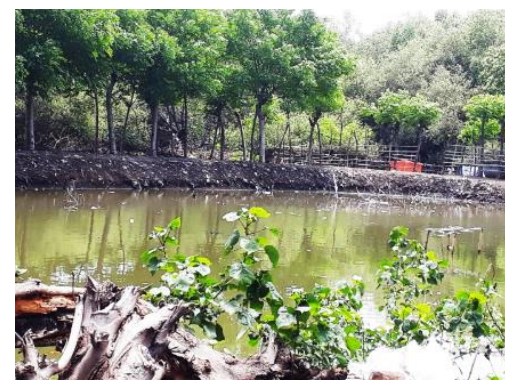

(a)

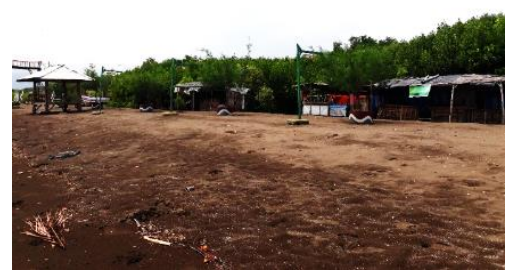

(b)

Gambar 16: (a) Garis pantai terdahulu yang membentuk genangan (b) Garis pantai sekarang di depan area mangrove

Selain itu terdapat pula area lain yang mengalami akresi. Seperti daerah muara sungai. Daerah muara Sungai Lobawang memiliki laju akresi tertinggi dibanding Sungai Deluang dan Sungai Gardu Rusak. Daerah muara Sungai Lobawang ini memiliki kemiringan landai sebesar $0,18 \mathrm{~m}$ dan ketinggian gelombang $0,15 \mathrm{~m}$. Nilai kemiringan dan gelombang ini merupakan nilai yang paling rendah daripada muara sungai 
lainnya. Laju akresi di muara sungai ini sebesar 0,311. Pada daerah ini terjadi penambahan sedimen di sisi timur muara sungai sampai di depan revetment daerah pemukiman di Kecamatan Besuki (Gambar 17).

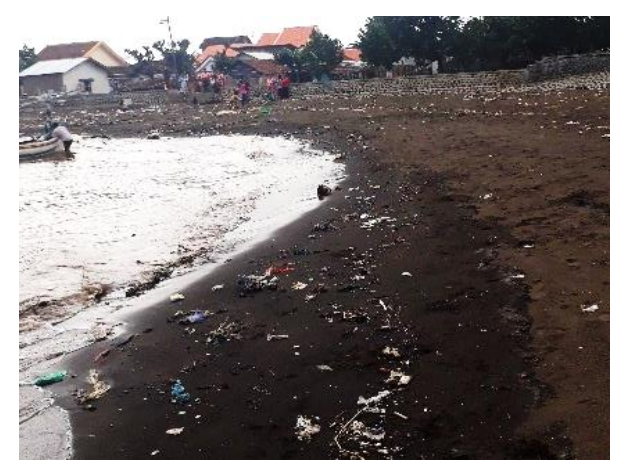

Gambar 17. Muara Sungai Deluang

Adanya muara sungai dapat mempengaruhi perubahan garis pantai. Aliran sungai membawa partikel sedimen dari daratan menuju ke laut dapat mengendapkan sedimen yang terbawa. Oleh sebab itu, daerah setelah muara Sungai Lobawang, Deluang, dan Gardu Rusak cenderung mengalami pertambahan sedimen dan garis pantainya menjadi maju. Muara sungai Deluang merupakan muara sungai terbesar daripada sungai Lobawang dan Gardu Rusak. Akan tetapi kemiringan Sungai Deluang lebih curam dibanding muara sungai lainnya dan tidak terdapat mangrove. Sehingga laju akresi di muara sungai Deluang lebih rendah daripada muara sungai yang lain karena tidak ada mangrove yang berfungsi sebagai penahan sedimen. Penambahan sedimen dapat mengakibatkankan berubahnya pola arus di sekitar muara sungai. Selain itu terbentuknya tanah kosong dari endapan sedimen dapat mengakibatkan konflik sosial antara masyarakat sekitar dengan pemerintah mengenai pemanfaatan lahan pada daerah tersebut.

Selain di daerah muara sungai, akresi juga terjadi di daerah mangrove. Pada daerah mangrove yang kemiringan pantainya landai dan tinggi gelombangnya rendah mengakibatkan tipe gelombang yang terbentuk adalah tipe pembentuk pantai sehingga cenderung mengalami sedimentasi. Adanya mangrove dapat mendukung terjadinya penambahan sedimen karena akar mangrove dapat menjebak sedimen untuk mengendap di area tersebut dan memungkinkan untuk terjadi akresi. Secara keseluruhan, di pesisir barat Kabupaten Situbondo diprediksi akan mengalami akresi dengan laju rata-rata sebesar $0,217 \mathrm{~m} /$ tahun. Pada penelitian ini, daerah yang mengalami akresi adalah daerah mangrove dan muara sungai, seperti mangrove Kecamatan Banyuglugur, muara Sungai Lobawang, muara Sungai Deluang, Pantai Dubibir, mangrove Kecamatan Suboh, dan muara Sungai Gardu Rusak.

Berdasarkan hasil dari perubahan garis pantai yang terjadi selama tahun 2009-2019 dan prediksi garis pantai menggunakan oneline model 5-25 tahun, terdapat lokasi yang mengalami erosi maupun akresi. Distribusi sedimen di lokasi penelitian menunjukkan pola erosion hingga transport as bed load.

Tabel 4. Hubungan perubahan garis pantai dengan transpor sedimen

\begin{tabular}{llllll}
\hline No. & \multicolumn{1}{c}{ Lokasi } & Stasiun & $\begin{array}{c}\text { Citra GE } \\
(\mathbf{2 0 0 9 - 2 0 1 9 )})\end{array}$ & $\begin{array}{c}\text { Prediksi } \\
(\mathbf{5 - 2 5} \text { tahun })\end{array}$ & $\begin{array}{c}\text { Jenis Transpor } \\
\text { sedimen }\end{array}$ \\
\hline 1. & Pantai Tampora & 1 & Erosi & Erosi & Erosion \\
2. & Pemukiman Banyuglugur & $2-4$ & Erosi & Erosi & Erosion \\
3. & Mangrove Banyuglugur & $5-8$ & Akresi & Akresi & Erosion \\
4. & Muara Sungai Lobawang & $9-11$ & Akresi & Akresi & Transport as bed load \\
5. & Muara Sungai Deluang & $12-16$ & Akresi & Akresi & Erosion \\
6. & Pantai Dubibir & 17 & Akresi & Akresi & Transport as bed load \\
7. & Mangrove Kecamatan Suboh & $18-19$ & Akresi & Akresi & Transport as bed load \\
8. & Tambak Kecamatan Suboh & 20 & Erosi & Erosi & Erosion \\
9. & Pemukiman Mlandingan & 21 & Erosi & Erosi & Erosion \\
10. & TPI Pesisir Mlandingan & 22 & Erosi & Erosi & Erosion \\
11. & Muara Sungai Gardu Rusak & $23-25$ & Akresi & Akresi & Transport as bed load \\
\hline
\end{tabular}


Hasil dari perubahan garis pantai menggunakan citra satelit Google Earth, prediksi menggunakan one-line model, dan transpor sedimen pada stasiun daerah penelitian memiliki pola yang sama. Apabila daerah yang mengalami garis pantai yang mundur, maka pola transpor sedimennya berupa erosion. Daerah yang mengalami garis pantai yang maju, menunjukkan pola transpor sedimen berupa transport as bed load.

Pada daerah mangrove Kecamatan Banyuglugur (Gambar 18) dan muara Sungai Deluang (Gambar 19), antara perubahan garis pantai menggunakan citra satelit Google Earth, one-line model, dan transpor sedimen tidak memiliki pola yang sama. Hasil citra dan prediksi menunjukkan bahwa di daerah tersebut akresi, sedangkan pola transpor sedimennya berupa erosion. Hal tersebut disebabkan telah terjadinya hujan di hari sebelumnya yang mengakibatkan debit air lebih banyak. Selain itu pengukuran dilakukan saat menuju surut sehingga kecepatan arus di area tersebut cukup kencang.

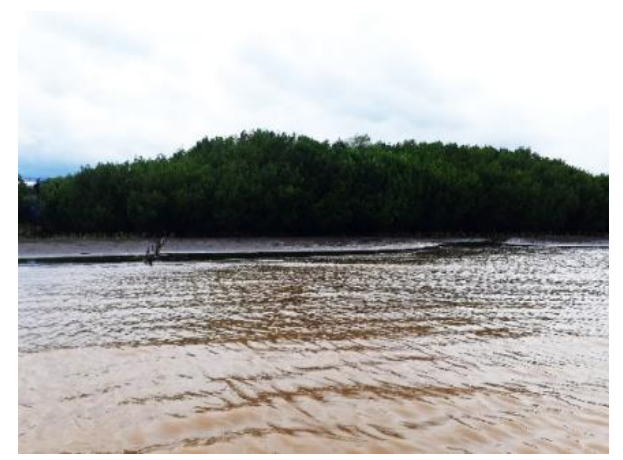

Gambar 18. Mangrove Kecamatan Banyuglugur

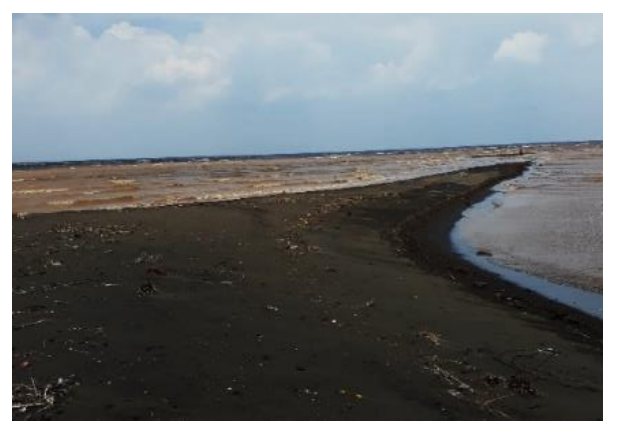

Gambar 19. Muara Sungai Deluang

\section{KESIMPULAN}

Berdasarkan hasil prediksi perubahan garis pantai di pesisir bagian barat Kabupaten Situbondo didapatkan kesimpulan sebagai berikut:

1. Prediksi perubahan garis pantai dilakukan dengan metode one-line model dan data yang dibutuhkan berupa koordinat garis pantai, kemiringan pantai, dan gelombang. Perhitungan masuk dan keluarnya sedimen pada model ini menggunakan rumus CERC yang cocok dengan jenis sedimen di lokasi penelitian. Daerah pesisir bagian barat Kabupaten Situbondo diprediksi mengalami erosi dan akresi. Erosi terjadi di daerah yang memiliki kemiringan pantai yang curam, tinggi gelombang yang relatif tinggi, dan tidak terdapat peredam energi gelombang. Akresi dominan terjadi di daerah yang memiliki kemiringan yang landai dengan gelombang yang rendah. Adanya mangrove dapat berpotensi terjadinya penambahan sedimen, sebab akar mangrove akan menahan sedimen sehingga terbentuk lahan baru. Selain itu adanya muara sungai juga berpeluang di lokasi muara sungai mengalami akresi. Hal ini disebabkan oleh aliran sungai yang membawa partikel sedimen dari daratan akan mengendapkan sedimen di sekitar muara sungai. Lokasi yang diprediksi mengalami erosi tertinggi adalah lokasi Pantai Tampora dengan laju 0,562 m/tahun dan akresi tertinggi terdapat di lokasi Pantai Wisata Dubibir dengan laju sebesar 0,632 $\mathrm{m} /$ tahun.

2. Hasil perubahan garis pantai terdahulu, prediksi, dan transpor sedimen memiliki pola yang sama. Pada lokasi yang mengalami garis pantai yang mundur, pola transpor sedimennya termasuk dalam kategori erosion. Sedangkan lokasi yang mengalami garis pantai yang maju memiliki pola yang termasuk dalam kategori transport as bed load. Secara umum daerah penelitian cenderung mengalami akresi dengan laju 0,217 $\mathrm{m} /$ tahun. Adanya pertambahan sedimen ini dapat mempengaruhi berubahnya pola arus di muara sungai serta berpeluang terjadinya 
konflik sosial akibat terbentuknya lahan baru.

\section{UCAPAN TERIMA KASIH}

Penelitian ini dibiayai oleh Grant Marine Resources Exploration dan Management (MEXMA), Fakultas Perikanan dan Kelautan, Universitas Brawijaya, tahun 2020.

\section{DAFTAR PUSTAKA}

[1] Sukandar, C. J Harsindhi, M. Handayani, C. S. U. Dewi, A. W. Maulana, Supriyadi, Dan A. Bahroni. Profil Desa Pesisir Provinsi Jawa Timur, Vol. 1 (Utara Jawa Timur). Surabaya: Bidang Kelautan, Pesisir, dan Pengawasan Dinas Perikanan dan Kelautan Provinsi Jawa Timur 2016.

[2] A. Budisusetyo, "Kajian Ekonomi Pengelolaan Hutan Mangrove (Studi Kasus di Pesisir Pantai Situbondo)," Jurnal Pertanian Agritop. 2009.

[3] Y. Arafat dan N. Hidayat, "Model Perubahan Garis Pantai Rerang (Kabupaten Donggala) Menggunakan Genesis," Jurnal Ilmiah Agrisains, Vol. 1, no. 1, hlm. 18-25. 2011.

[4] F. Kasim, "Laju Perubahan Garis Pantai Menggunakan Modifikasi Teknik Single Transect (ST) dan Metode End Point Rate (EPR): Studi Kasus Pantai Sebelah Utara Indramayu-Jawa Barat," Jurnal Ilmiah Agropolitan, vol. 3, no. 2. 2010.

[5] N. Hidayati, Dinamika Pantai. Malang: UB Press. 2017.

[6] A. A. Akbar, J. Sartohadi, T. S. Djohan, dan S. Ritohardoyo, "Erosi Pantai, Ekosistem Hutan Bakau dan Adaptasi Masyarakat terhadap Bencana Kerusakan Pantai di Negara Tropis" $J$. Ilmu Lingkungan., vol. 15, no. 1, hlm. 110. Mei 2017. DOI: 10.14710/Jil.15.1.110.
[7] T. Aris, "Analisis Tipe Psang Surut di Perairan Utara Jawa Timur," Skripsi: Universitas Brawijaya, Malang. 2017.

[8] U. Hernawan, N. Y. Gerurnaheu, dan L. Godwin, "Karakteristik Pantai dan Bahaya Abrasi di Pulau Putri, Nongsa, Batam," Oseanologi dan Limnologi di Indonesia, vol. 3, no. 2, hlm. 137-153. 2018.

[9] S. Purnawan, "Kajian Awal Granulometri Pada Kawasan Lamun dan Terumbu Karang: Studi Kasus di Gugusan Pulau Pari, Kepulauan Seribu," Depik, vol. 4, no. 2. Sep 2015. DOI: 10.13170/Depik.4.2.2640.

[10] S. H. Nugroho dan A. Basit, "Sebaran Sedimen Berdasarkan Analisis Ukuran Butir di Teluk Weda, Maluku Utara," Jurnal Ilmu dan Teknologi Kelautan Tropis, vol. 6, no. 1, hlm. 229-240. 2014.

[11] M. Ramli, R. D. Putra, dan C. J. Koenawan, "Pola Sebaran Sedimen Permukaan Berdasarkan Kedalaman Perairan di Pelabuhan Internasional Ferry Dompak Tanjungpinang," Jurnal Umrah. 2017.

[12] M. A. Z. Fuad, N. Yunita, R. D. Kasitowati, N. Hidayati, dan A. Sartimbul, "Pemantauan Perubahan Garis Pantai Jangka Panjang dengan Teknologi Geo-Spasial di Pesisir Bagian Barat Kabupaten Tuban, Jawa Timur," Jurnal Geografi, vol. 11, no. 1. Feb 2019. DOI: 10.24114/Jg.V11i1.11409.

[13] N. Hidayati, Aut W. Paluphi, M. A. Asadi, dan H. S. Purnawali, "Kajian Dinamika Pantai : Studi Kasus di Pantai Rening, Jembrana, Bali," Depik, vol. 6, no. 1, hlm. 31-43. Mar 2017. DOI: 10.13170/Depik.6.1.5457.

[14] D. E. Kalay, L. Villian F., dan Y. A. Noya, "Analisis Kemiringan Lereng Pantai dan Distribusi Sedimen Pantai Perairan Negeri Waai Kecamatan Salahutu Provinsi Maluku," Jurnal Triton, vol. 14, no. 1, hlm. 10-18. 2018. 